\title{
Unsteady Flow and River Bed Stratification Mutual Impact on Scour at the Abutments
}

\author{
B. Gjunsburgs(1), J. Parilkova(2) \\ (1) Riga Technical University, Department of Water Engineering and Technology, Kipsala Str. 6A, LV-1048, Riga, LATVIA \\ e-mail: boriss.gjunsburgs@gmail.com \\ (2) Brno University of Technology, Department of Water Structures, Veveri 95, 60200, Brno, CZECH REPUBLIC
}

\section{SUMMARY}

The floods of different probability, sequence, frequency, duration, and the riverbed with different grain sizes, numbers, sequences, and thickness of the layers are one of the reasons for the bridge's abutments failure because of scour. Although the problem is very topical, the mutual impact of multiple floods and stratified riverbed conditions on scour at the bridge abutments has not been studied. The method for computing scour development in time at bridge abutments was elaborated and confirmed by tests results. The method enables the computer to perform modelling of the mutual impact of unsteady flow and bed layering of scour processes. Computer modelling was made to expand scenarios for tests data in flume for unsteady flow for two steps of hydrograph with different dischargers and for the bed layers with varying grain sizes, numbers, sequence, and thickness. This approach makes it possible to estimate in advance mutual impact, with different scenarios, floods and geological data on the depth of scour at vertical wall abutment, at the design stage or during the maintenance period of the bridge crossing.

KEY WORDS: $\quad$ flow; , unsteady flow; bed stratification; scour; bridges; modelling.

\section{INTRODUCTION}

The mutual impact of floods and layering of the riverbed is one of the reasons for the bridge abutments failure because of scouring. To forecast worst scenarios of possible loads on the bridge inflow, floods of different probability, sequence, duration, and frequency should be considered and the river bed layers with different grain sizes, numbers, sequences, and thickness impact on the scour evaluation should be estimated. Analysis of the possible scenarios of the local scour development near abutments with time can be performed at the design or the maintenance stages of the bridge crossing and, as a result, protection measures can be taken in time.

Scours near bridge piers, abutments, spur dikes, guide bank and intakes have been widely studied by researchers: Kothyari and Ranga Raju (2001) [1], Olivetto and Hager (2002) [2], Radice et al. (2002) [3], Malavasi, et al. (2004) [4], Dey and Barbhuiya (2005) [5], Grimaldi et al. 
(2006) [6], Cardoso and Fael (2010) [7], Ghani et al. (2011) [8], Guo (2014) [9], Sheppard et al. (2014) [10], Evangelista et al. (2017) [11], Link et al. (2017) [12] and the others. As the analysis of the literature shows, at the present time, there are no methods or formulas to calculate the depth of scour at mutual impact floods and complex geological river bed conditions.

The differential equation for equilibrium bed-sediment movement under clear water conditions, at unsteady flow or at uniform and stratified bed at the vertical wall abutments was used to create the model for the depth of scouring calculation. Based on the model the computer program ARobo was performed. The calculation method for scour development in unsteady flow (Gjunsburgs et al. 2013) [13] or at the stratified bed (Gjunsburgs et al. 2012, 2019) [14,15] was confirmed by test results. The method allows the computer to perform modelling of the mutual impact of unsteady flow and bed layering of scour processes. Modelling was made to expand scenarios for test data in flume for unsteady flow and bed stratification layers with changing grain sizes, numbers, sequences, and thickness on scour at vertical wall bridge abutments. The model and the ARobo program allow analysis performing and finding the worst possible scenarios for scour evaluation near bridge abutments at the natural flow conditions.

\section{EXPERIMENTAL SET-UP}

The tests were carried out in a flume $L=3.5 \mathrm{~m}$ wide and $L_{f}=21 \mathrm{~m}$ long. Cross-section of the flume with different flow opening is presented in Figure 1.

Experimental data obtained in flumes in the open flow conditions are presented in Table 1. The flow distribution between the channel and floodplain was studied under open flow conditions. The rigid bed tests were performed to investigate flow modification near bridge structure and sand-bed tests were made to study the scour development with time under different flow parameters and at uniform or stratified river bed model.

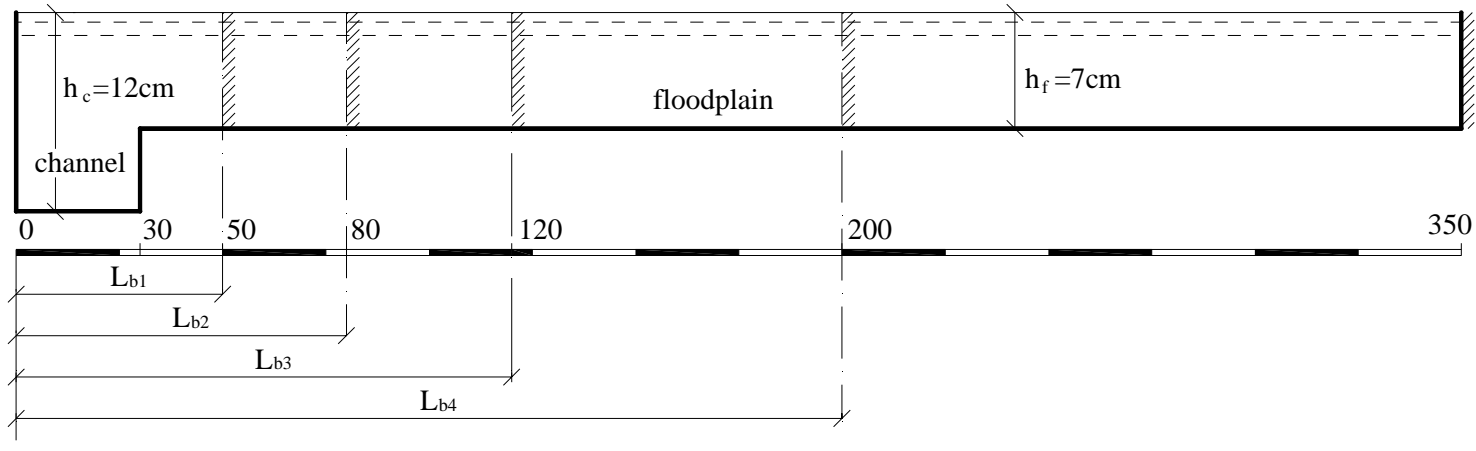

Fig. 1 Cross section of the flume with different flow opening $L_{b i}$

Table 1 Test data for the open flow conditions

\begin{tabular}{|c|c|c|c|c|c|c|c|}
\hline & $\begin{array}{c}L \\
\mathrm{~cm}\end{array}$ & $\begin{array}{c}h_{f} \\
\mathrm{~cm}\end{array}$ & $\begin{array}{c}V_{a p} \\
\mathrm{~cm} / \mathrm{s}\end{array}$ & $\begin{array}{c}Q \\
\mathrm{l} / \mathrm{s}\end{array}$ & $F r$ & $\operatorname{Re}_{c}$ & $\operatorname{Re}_{f}$ \\
\hline$L 1$ & 350 & 7 & 6.4 & 16.6 & 0.078 & 7500 & 4390 \\
\hline$L 2$ & 350 & 7 & 8.5 & 22.7 & 0.103 & 10010 & 6060 \\
\hline$L 3$ & 350 & 7 & 10.0 & 23.60 & 0.124 & 12280 & 7190 \\
\hline$L 7$ & 350 & 13 & 7.5 & 35.48 & 0.066 & 13700 & 9740 \\
\hline$L 8$ & 350 & 13 & 8.7 & 41.38 & 0.075 & 16010 & 11395 \\
\hline$L 9$ & 350 & 13 & 9.9 & 47.10 & 0.087 & 14300 & 14300 \\
\hline
\end{tabular}


The tests were made: 1 . for unsteady flow and uniform bed and 2. for steady flow and stratified bed conditions.

For unsteady flow tests, the openings of the bridge model were $(50,80,120$, and 200$) \mathrm{cm}$. The flow contraction rate $Q / Q_{b}$ (where $Q$ is the flow discharge and $Q_{b}$ is the discharge in the opening under open-flow conditions) varied respectively from 1.56 to 5.69.

Tests with stratified bad were made with different grain sizes $0.24 \mathrm{~mm}$ and $0.67 \mathrm{~mm}$, with a standard deviation and the thickness of the bed layers equal to $(4,7$, or 10$) \mathrm{cm}$ for each grain size. The opening of the bridge model was $80 \mathrm{~cm}$.

For both types of the tests: the floodplain width was $L_{f}=320 \mathrm{~cm}$ and the depth $h f$ was $7 \mathrm{~cm}$ or 13 $\mathrm{cm}$. The channel width was $L_{c}=30 \mathrm{~cm}$ and depth $h_{c}$ was $12 \mathrm{~cm}$ or $18 \mathrm{~cm}$, the approach flow velocity $V_{a p}$ changing from 6.4 to $10.0 \mathrm{~cm} / \mathrm{s}$, the flow dischargers varying from 16.6 to $47.1 \mathrm{l} / \mathrm{s}$, with the Froude number in the open-flow conditions from 0.078 to 0.1243 , densimetric Froude numbers - from 0.62 to 1.65 , the slope of the flume was equal to 0.0012 . The scour evaluation was studied within one 7 hour step-time interval and within two 7 hour step-time search.

The condition $F r_{R}=F r_{f}$ was fulfilled, where $F r_{R}$ and $F r_{f}$ are the Froude numbers for the low-land river and the flume, respectively.

Computer modelling was made to study the mutual impact of unsteady flow and stratified bed model on scour, and to expand scenarios for tests data in flume for unsteady flow for two timesteps of hydrograph with dischargers: $1.16 .7 / 35.5 \mathrm{l} / \mathrm{sec}$; 2. 22.7/41.4 l/sec; 3. 27.6/47.1 l/sec, contraction rate $3.66-4.05$, floodplain depth $7 \mathrm{~cm}$ and $13 \mathrm{~cm}$, layers with grain sizes $(0.24,0.67$ and $1.00 \mathrm{~mm}$, up to 3 layers with changing sequence of the grain sizes and thickness of the bed layers, with the opening of the bridge model equal to $80 \mathrm{~cm}$.

\section{MODEL}

The method for calculating the scour development with time at the abutments, guide banks, intakes during the multiple floods, or at stratified bed was elaborated and confirmed with experimental data (Gjunsburgs et al. 2004, 2012, 2013, 2019) [14,13,15].

There are many scenarios for multiple floods of different probability, sequence, duration, frequency, and the layers of the river bed as uniform layers with different grain sizes, sequence, non- uniform layers, cohesive layers follow or before non- cohesive layers, number of layers.

Computer program ARobo allows studying, analysing scenarios with the use of additional data for different hydraulic conditions, contraction rates, Froude number of the open flow, densimetric Froude numbers, depths of the flow, backwater, as well as parameters which reflect the river bed conditions: grain size diameter $d_{50}$, critical velocity $\beta V_{o}$ or grain bed shear stress, sediment non-uniformity parameter $\sigma$, specific weight $\gamma$, bed layering, numbers, sequences and thickness of the layers with grain sizes $d_{i}$.

According to the method, the hydrograph was divided into time steps, and each step was subdivided into time intervals. Calculations were performed for two steps of the hydrograph, to estimate the influence of the flow unsteadiness. The parameter $A_{s}$ in proposed model (Gjunsburgs et al. 2012, 2013) [14,13] changes during the scour evolution because water depth, local velocity and critical velocity changes with time and as well as the river bed layering grain size diameter, so that: 


$$
A_{s}=\frac{0.002}{g}\left(1-\frac{k \beta V_{0}}{V_{l}}\left(1+\frac{h_{s}}{2 h_{f}}\right)^{1.25}\right) \frac{1}{g^{0.5}\left(h_{f} d\right)^{0.25}\left(1+\frac{h_{s}}{2 h_{f}}\right)^{0.25}},
$$

where:

$$
\frac{\beta V_{o t}}{V_{l t}}=\frac{k \beta V_{0}}{V_{l}}\left(1+\frac{h_{s}}{2 h_{f}}\right)^{1.25} .
$$

With an increase of the scour depth, the local velocity $V_{l t}$ is decreasing due to the scour $h_{s}$ and increasing because discharge increases (as sequence $V_{l}$ increases), the critical one $\beta V_{o t}$ is increasing because of scour depth $h_{s}$ and varying with $d_{i}$ in bed layers (Eq. 2). Scouring stops when the local velocity becomes equal to the critical on $V_{l t}=\beta V_{o t}$ :

$$
\frac{V_{l}}{k\left(1+\frac{h_{s}}{2 h_{f}}\right)}=\beta \cdot 3.6 \cdot d_{i}^{0.25} \cdot h_{f}^{0.25}\left(1+\frac{h_{s}}{2 h_{f}}\right)^{0.25},
$$

where $V_{l}$ is the local velocity, $V_{o}$ - the critical velocity, $h_{s}$ - the depth of scour, $h_{f}$ - the depth of water on the floodplain, $d_{i}$ - the grain size diameter, $\beta$ - the coefficient of critical velocity reduction near the abutment. The model allows estimating mutual impact - discharge, relative velocity changes in time at varying numbers, sequence, and thickness of bed layers with different grain size $d_{i}$ on the depth of scour at the abutments.

\section{RESULTS}

The depth of scour is rapidly increasing at the beginning of the scouring process with the gradual reduction in time at a steady flow and one bed layer. Further computer modelling results are presented for extended laboratory data for two steps of hydrograph and with different grain sizes, numbers, sequences, and thickness of the bed layers.

Figure 2 presents calculated and test data for scour depth evaluation in time at an unsteady flow and one bed layer. The depth of scour is increasing at the first interval, which is equal to 7 hours and is increasing more rapidly (Figure 1) at the second time interval, because of the new hydraulic parameters.

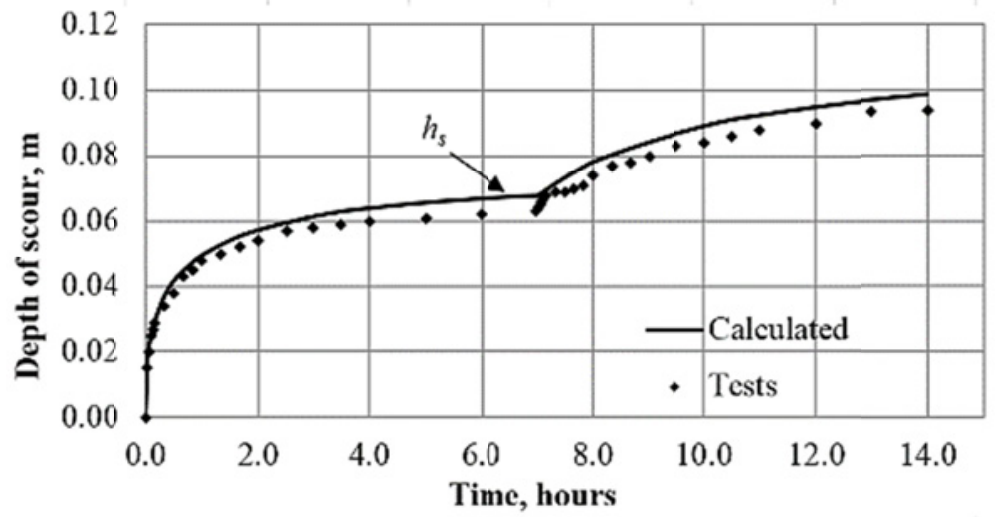

Fig. 2 Depth of scour development in time at unsteady flow in one uniform layer 
Figure 3 presents the depth of scour evolution at an unsteady flow with $Q_{1}=22.7 \mathrm{l} / \mathrm{sec}$ and $Q_{2}=41.4 \mathrm{l} / \mathrm{sec}$ with the sequence of the layers with grain sizes $(1.00,0.67$, and 0.24$) \mathrm{mm}$ with the thickness of the layers $4.6 \mathrm{~cm}$ and $10 \mathrm{~cm}$. The rate of the scouring depends on $d_{i}$ and increases more rapidly at the second time interval with $Q_{2}=41.4 \mathrm{l} / \mathrm{sec}$ and in the third layer with fine grain size (Figure 3).

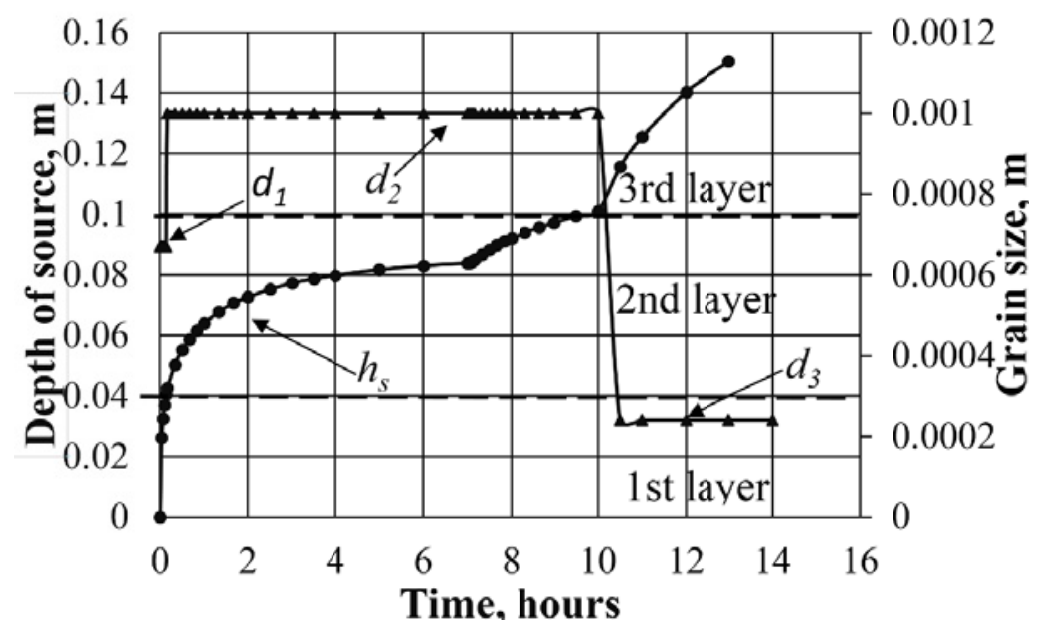

Fig. 3 Depth of scour evaluation at an unsteady flow in three layers

Figure 4 shows relative velocity changes in time because of the scour evolution at unsteady flow with $Q_{1}=22.7 \mathrm{l} / \mathrm{sec}$ and $Q_{2}=41.4 \mathrm{l} / \mathrm{sec}$ with the sequence of the layers with grain sizes $(1.00,0.67$, and 0.24$) \mathrm{mm}$ with the thickness of the layers $4.6 \mathrm{~cm}$ and $10 \mathrm{~cm} \mathrm{r}$. With the increase of the depth of scour, the relative velocity $V_{l t} / V_{o t}$ increases in the first time interval and reduces at the second one because of the increase of the local velocity $V_{l}$ and the reduction of the critical velocity $\beta V_{o t}$ in the layer with $d_{3}=0.24 \mathrm{~mm}$ (Eq. 2).

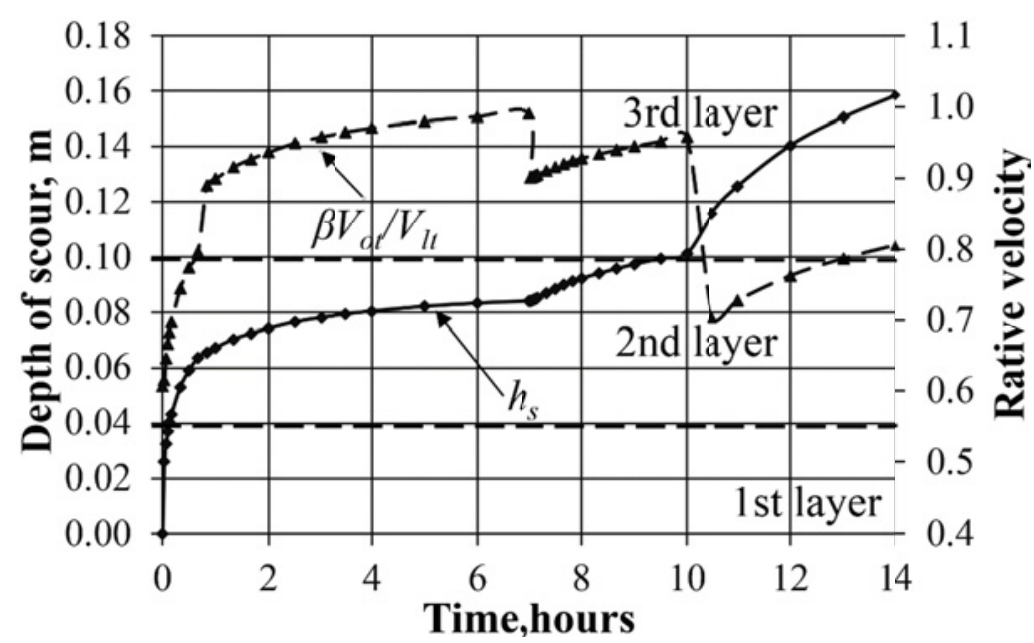

Fig. 4 Relative velocity changes versus depth of scour at unsteady flow and three layers

Impact of unsteady flow with discharges $16.7 / 35.5 \mathrm{l} / \mathrm{sec}$ or $27.1 / 47.1 \mathrm{l} / \mathrm{sec}$ on the depth of scour for three layers with $d_{i}-(1.0,67,0.24) \mathrm{mm}$ of each layer with thickness $(4,6,10) \mathrm{cm}$ is shown in Figure 5. As discharge increases the scour depth is increasing. 


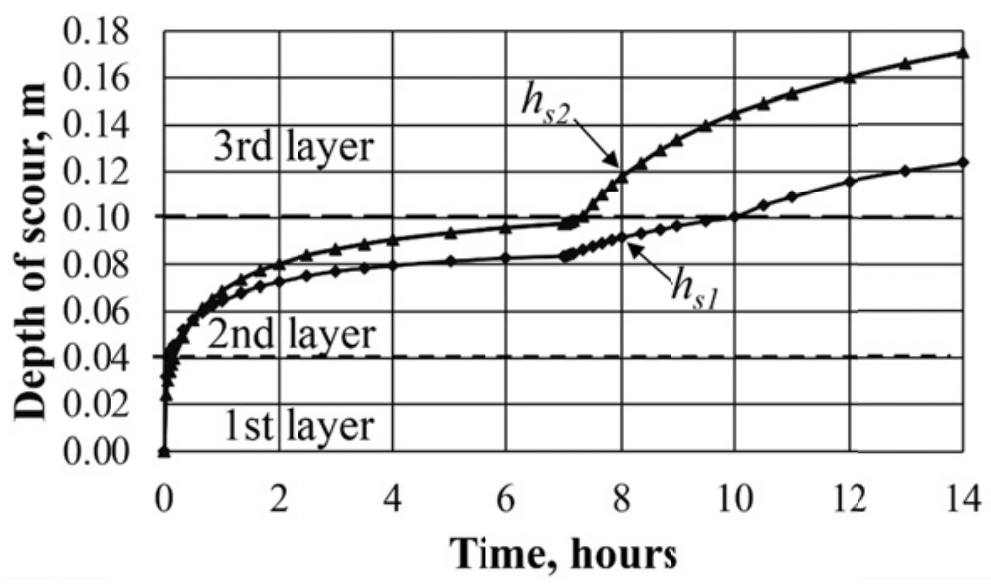

Fig. 5 Depth of scour development in two time steps with different discharges in three layers

Depth of scour in two layers with $d_{i}-(1.00,0.24) \mathrm{mm}$ with the thickness of the layers 5 and 10 $\mathrm{cm}$, and in three layers with $d_{i}-(1.00,0.67,0.24) \mathrm{mm}$ and with the thickness of 10,5 , and 10 $\mathrm{cm}$. For the same time step is presented in Figure 6. With the addition of a third layer of $d_{i}=$ $0.67 \mathrm{~mm}$, the depth of scour reduces.

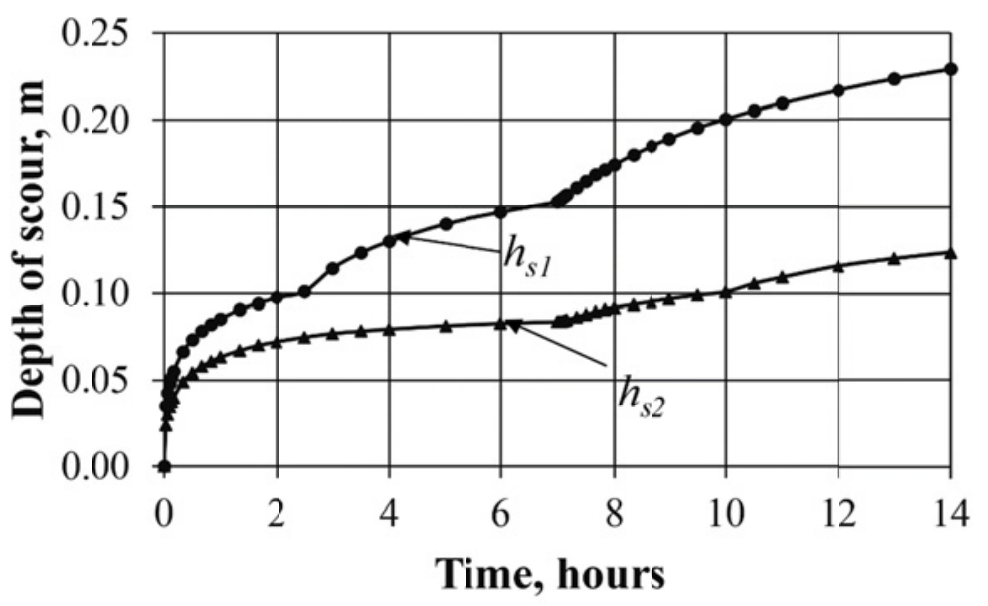

Fig. 6 Depth of scour evaluation in two layers with $d_{i}-1.00 \mathrm{~mm}, 0.24 \mathrm{~mm}$ with thickness $5 \mathrm{~cm}, 10 \mathrm{~cm}\left(h_{s 1}\right)$ and in three layers with $d_{i}-(1.00,0.67,0.24) \mathrm{mm}$ and with thickness $(10,5,10) \mathrm{cm}\left(h_{\mathrm{s} 2}\right)$

With an increase in the thickness of the fine sand layer $d_{i}-0.24 \mathrm{~mm}$, the depth of scour increases (Figure 7). Comparison is made for grain sizes for each layer $(0.24,0.67,1.00) \mathrm{mm}$ and different thickness of the fine send layer $-(15,5,10) \mathrm{cm}\left(h_{1}\right)$ or $(5,5,10) \mathrm{cm}$. $\left(h_{2}\right)$. 


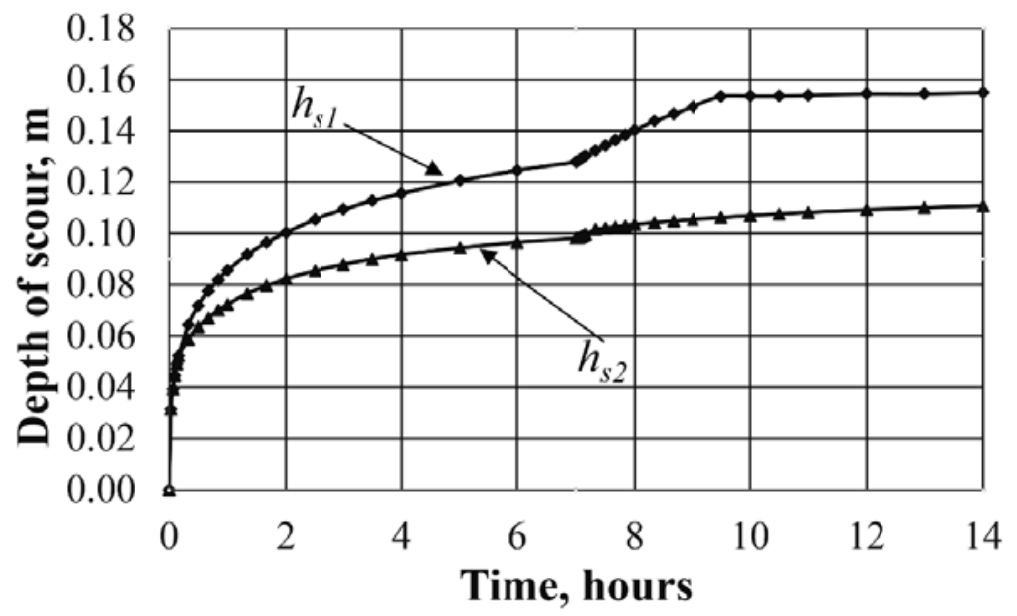

Fig. 7 Depth of scour comparison for three layers and two layers with thickness for the first fine sand one equal $15 \mathrm{~cm}$ or $5 \mathrm{~cm}$

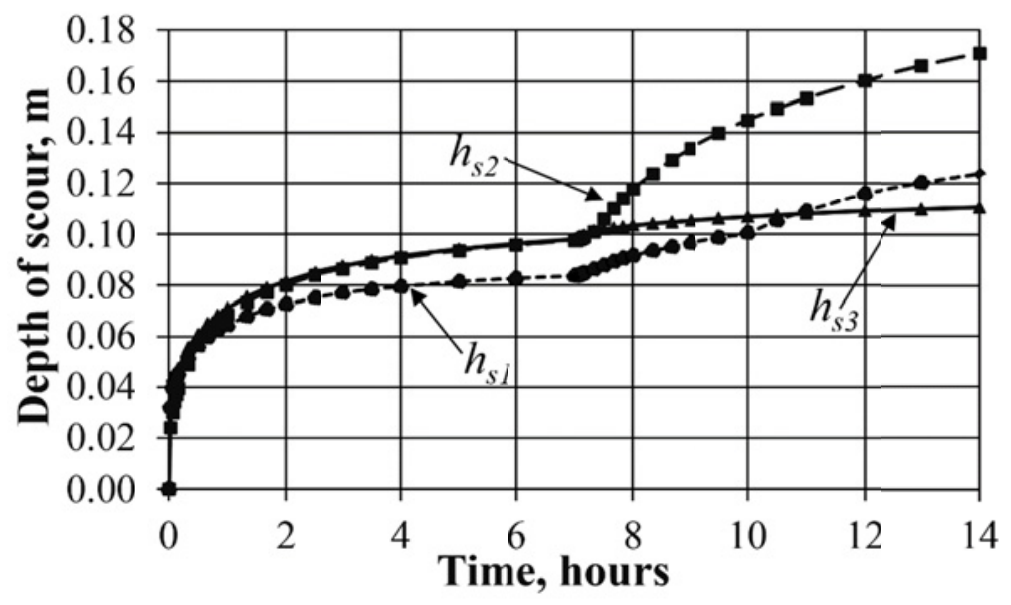

Fig. 8 Depth of scour evolution at unsteady flow and different sequence of the layer

Figure 8 presents the depth of scour evolution at an unsteady flow and different sequence of the layers. Sequence of layers are grain size diameters: $(0.24,1.00,0.67) \mathrm{mm} ;(1.00,0.67,0.24)$ $\mathrm{mm}$ and $(0.24,0.67,1.00) \mathrm{mm}$ and with the same thickness of the layers $4.6 \mathrm{~cm}$ and $10 \mathrm{~cm}$. The coarse sand on the top layers increases the time of scour and reduces scour depth. For layers with $d_{i}$ reduction, when the first two layers are washed out the depth of scour rapidly develops at the fine sand layer and gives greater scour depth (Figure 7).

\section{CONCLUSION}

The damage of engineering structures in rivers due to scour (near intakes, pumping stations, bridge structures - abutments, guide banks, dams, etc.) leads to the considerable environmental and economic losses. The reasons are the mutual impacts of multiple floods, river bed geology, flow contractions, type and shape of the structure, and increasing scour hole, which under clear-water conditions is summing up from flood to flood. Increased dimensions of the scour hole at the unexpected flush flood can lead to damage or bridge failure. 
The models for calculation of scour development in an unsteady flow (Gjunsburgs et al. 2013) [13] or at stratified bed (Gjunsburgs et al. 2012, 2019) [14,15] were elaborated and confirmed by test results, which enabled to make computer modelling to study the mutual impact of an unsteady flow and bed layering on the depth of scour.

Computer modelling was made to expand scenarios for test data in flume for an unsteady flow for two steps of hydrograph with dischargers: first 16.7/35.5 l/sec; second 22.7/41.4 l/sec; third 27.6/47.1 l/sec, and contraction rates $3.66-4.05$, floodplain depths of $7 \mathrm{~cm}$ and $13 \mathrm{~cm}$, layers with grain sizes $0.24,0.67$, and $1.00 \mathrm{~mm}$, with up to 3 numbers, changing sequence and with the thickness $4 \mathrm{~cm}-10 \mathrm{~cm}$ of the bed layers.

As it is confirmed by calculation, the rate and value of scour depth depend on the mutual impact of an unsteady flow and river bed stratification (grain size $d$, numbers, sequences, and thickness of the layers). There are changes in scour depth evaluation with increased discharge and grain diameter in layers (Figure 3) and/or discharges (Figure 5), numbers (Figures 6 and 7), and sequence (Figure 8) of the layers. Relative velocity $V_{l t} / V_{o t}$ increases in time steps of hydrograph and in any sand layer (Figure 3), when the ratio of the velocities becomes equal, the scour evaluation stops.

Model and ARobo program can detect worst possible scenarios in nature for scour evaluation at the abutments at an unsteady flow: for floods of different probability, sequence, duration or frequency and for river bed layering with different numbers, sequences and thickness of the layers with grain sizes $d_{i}$, at both the design and the maintenance stages of the bridge crossing.

\section{REFERENCES}

[1] U. Kothyari, K. Ranga Raju, Scour around spur dikes and bridge abutments, Journal of Hydraulic Research, Vol. 39, No. 4, pp. 367-374, 2001.

https://doi.org/10.1080/00221680109499841

[2] G. Oliveto, W. Hager, Temporal evolution of clear water pier and abutment scour, Journal of Hydraulic Engineering, ASCE 2002, Vol. 128, No. 9, pp. 811-820, 2002.

https://doi.org/10.1061/(ASCE)0733-9429(2002)128:9(811)

[3] A. Radice, S. Franzetti, F. Ballio, Local scour at bridge abutments, Proc. of Int. Conf. on Fluvial Hydraulics River Flow 2002, 4-6 September, Louvain-La-Neuve, Belgium, Vol. 2, pp. 1059-1068, Bousmar \& Zech eds., Lisse: Swets \& Zeitlinger, 2002.

[4] S. Malavasi, A. Radice, F. Ballio, Study of sediment motion in a local scour hole through an image processing technique, Proc. of Int. Conf. on Fluvial Hydraulics River Flow 2004, 23-25 June, Napoli, Italy, Vol. 1, pp. 535-542, Greco, Carravetta \& Della Morte eds., Taylor \& Francis Group, London, ISBN 9058096580, 2004.

https://doi.org/10.1201/b16998-70

[5] S. Dey, A. Barbhuiya, Time variation of scour at abutments, Journal of Hydraulic Engineering, Vol. 131, No. 1, pp. 11-23, 2005.

https://doi.org/10.1061/(ASCE)0733-9429(2005)131:1(11)

[6] C. Grimaldi, R. Gaudio, A. Cardoso, F. Calomino, Local scouring at bridge piers and abutments: time evolution and equilibrium, Proc. of Int. Conf. on Fluvial Hydraulics River 
Flow 2006, 6-8 September, Lisbon, Portugal, Vol. 1, pp. 1657-1664, Ferreira, Alves, Leal \& Cordoso eds, 2006.

[7] A. Cardoso, C. Fael, Time to equilibrium scour at vertical wall bridge abutments, Proc. of ICE-Water Management, Vol. 163, No. 10, pp. 509-513, 2010.

https://doi.org/10.1680/wama.900038

[8] A. Ghani, H. Azamathullah, R. Mohammadpour, Estimating time to equilibrium scour at long abutment by using genetic programming, Proc. of 3rd Int. Conf. on Managing Rivers in the 21st Century: Sustainable Solutions for Global Crisis of Flooding, Pollution and Water Scarcity, Rivers 2011, 6-9 December, Penang, Malaysia, pp. 369-374, 2011.

[9] J. Guo, Semi-analytical model for temporal clear-water scour at prototype piers, Journal of Hydraulic Research, Vol. 52, No. 3, pp. 366-374, 2014.

https://doi.org/10.1080/00221686.2013.877527

[10] D. Sheppard, B. Melville, H. Demir, Evaluation of existing equations for local scour at bridge piers, Journal of Hydraulic Engineering, Vol. 140, No. 1, pp. 14-23, 2014.

https://doi.org/10.1061/(ASCE)HY.1943-7900.0000800

[11] S. Evangelista, J. Govša, M. Greco, B. Gjunsburgs, Computation of Sediment Discharge in Rivers: The Contributions by Levi and Studenitcnikov Revisited, Journal of Hydraulic Research, Vol. 55, iss. 4, pp. 445-454, 2017.

https://doi.org/10.1080/00221686.2016.1274683

[12] O. Link, A. Pizarro, A. Rojas, B. Ettemer, C. Escauriaza, S. Manfreda, A model of bridge pier scour during flood waves, Journal of Hydraulic Research, Vol. 55, iss.3, pp. 310-32, 2017. https://doi.org/10.1080/00221686.2016.1252802

[13] B. Gjunsburgs, E. Govsha, G. Jaudzems, Influence of the River Bed Stratification on Scour at Foundations, Proceedings of the $35^{\text {th }}$ IAHR World Congress: $35^{\text {th }}$ IAHR World Congress. Chengdu: IAHR, Ministry of WR China, Vol. 4, 9 p, 2013.

[14] B. Gjunsburgs, G. Jaudzems, E. Govsha, Multiple Floods Impact on Scour at Engineering Structures, $6^{\text {th }}$ International Conference on Scour and Erosion Paris, 27-31 August, France: Societe Hydrotechnique de France, pp. 747-754, 2012.

[15] B. Gjunsburgs, M. Vilnītis, J. Parilkova, M. Bižāne, Impact Flow and Bed Layering on Equilibrium Depth of Scour at Elliptical Guide Banks, IOP Conference Series: Materials Science and Engineering, Vol. 660, pp. 133-140, ISSN 1757-8981, e-ISSN 1757-899X, 2019. https://doi.org/10.1088/1757-899X/660/1/012029

[16] B. Gjunsburgs, R. Neilands, R.R. Neilands, Scour development at bridge abutments on plain rivers during the flood: analysis of the method, Proc. of $2^{\text {nd }}$ Intern. Conf. Scour and Erosion ICSE-2, 14-17 November 2004, Meritus Mandarin, Singapore, Vol. 1, pp. 199206, Chiew, Lim \& Cheng eds., Singapore: Stallion Press, 2004. 